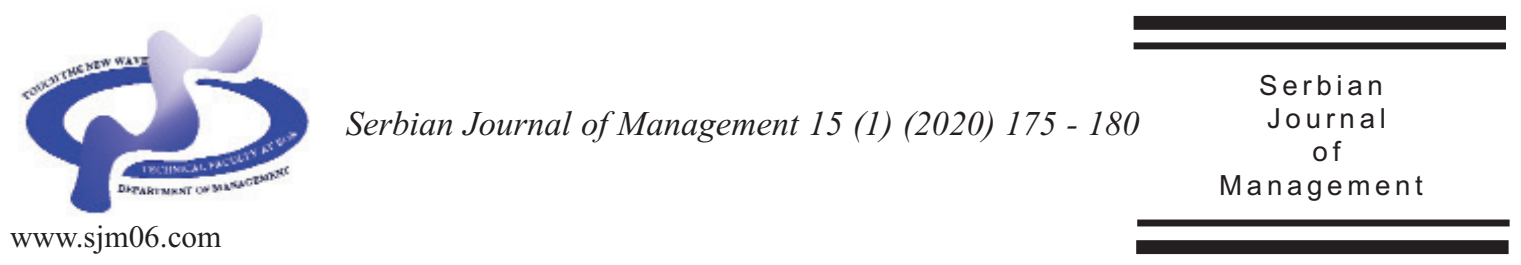

Short Communication:

\title{
DETERMINANTS OF CONSUMER BEHAVIOUR WHEN CHOOSING BETWEEN WHOLE AND SKIMMED UHT MILK
}

\author{
Kennya Beatriz Siqueira*a, Marielli Cristina de Pinhob, \\ Cristiano Amâncio Vieira Borges ${ }^{a}$ and Marco Antonio Sundfeld da Gama ${ }^{a}$
}

a Brazilian Agricultural Research Corporation - Embrapa: Rua Eugênio do Nascimento, 610, Dom Bosco, Juiz de Fora, MG, 36038-330, Brazil

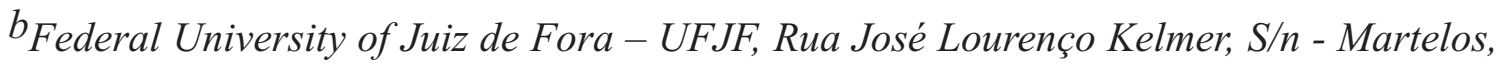
Juiz de Fora, MG, 36036-330, Brazil

(Received 03 April 2018; accepted 08 November 2018)

\begin{abstract}
Large amounts of UHT milk are consumed in Brazil, but little is known about the factors affecting the consumer's decision to choose between whole and skimmed UHT milk. Since consumers represent one of the main market drivers, it is important to identify the factors influencing their behavioral patterns. A structured questionnaire was applied to 248 people in Juiz de Fora, Brazil. A binary logistic regression model was used to analyze the probability of buying whole or skimmed UHT milk. Results indicated that income, age, and number of family members in a residence are the major determinants of consumer behaviour when choosing between whole and skimmed milk. Higher income, older people, and smaller number of residents were associated with an increased consumption of skimmed milk. These results could be useful to orientate local dairy market campaigns and logistic distribution of products according to consumer preferences.
\end{abstract}

Keywords: milk fat, dairy products, consumption, preferences

\section{INTRODUCTION}

Milk is an important source of nutrients in the human diet. Brazil has hundreds of fluid milk processors, and large amounts of Ultra High Temperature (UHT) milk are consumed in the country (IBGE, 2018). However, there is limited information regarding the factors influencing the consumer's decision in favor of whole or skimmed UHT milk.

Over the last four decades, the medical community and public health agencies of

\footnotetext{
* Corresponding author: kennya.siqueira@embrapa.br
}

DOI: $10.5937 /$ sjm15-17051 
many countries have recommended restricting the consumption of animal fat in order to reduce saturated fat intake (WHO, 2015). This recommendation is based on a number of studies showing that saturated fat increases total and LDL-cholesterol levels in the blood, which would supposedly increase the risk of cardiovascular diseases (Maijala, 2000). As full-fat dairy products (e.g. whole milk, cheeses, butter) are significant sources of saturated fatty acids in the human diet, the consumption of these products was drastically reduced in recent decades (replaced with low fat/fat free versions or vegetable sources such as margarine). However, this recommendation has been strongly questioned by recent meta-analysis of observational and randomized clinical trials which have indicated that dairy fat intake does not increase the risk of cardiovascular disease and is associated with a lower risk of obesity and type 2 diabetes (Kratz et al., 2013; Astrup, 2014; Mozaffarian, 2014; Yakoob et al., 2014).

These new scientific findings affected the consumption of certain dairy products such as butter, which had a boom of consumption in the last years (Siqueira, 2017). However, there is little information about possible changes in consumer preferences in favor of whole or skimmed milk. Since the impacts of scientific findings are difficult to measure, it would be useful to identify the factors affecting the consumers behavioral patterns. Indirectly, information on socioeconomic variables, price, and other factors affecting the preferences of the consumer for whole or skimmed milk could reflect the scientific impacts on fat in milk consumption preferences.

\section{LITERATURE REVIEW}

The literature on consumer's decisionmaking has documented numbers of factors which influence selection of food. These factors may include nutritional knowledge, product quality, costs, culture issues, sociodemographics factors, etc. Few studies have been publishing on whole and skim milk preferences.

Hatirli et al. (2004) studied the Turkish milk market and found that number of children, household size, educational level and income were among the important household characteristics that influence fluid milk purchasing behaviors in Turkey. In Rome, Saba et al. (1998) evaluated the characteristics of three types of milk, skimmed, semi-skimmed and whole fat. Habit was found to be more important than attitude in the prediction of the behavioural intention.

Grebitus et al. (2007) surveyed 260 households in Germany, in 2004, in order to analyze the impact of certain quality characteristics and socio-demographics on consumption patterns and marketing campaigns regarding whole fat milk, skim milk and organic milk. They found a great importance of the brand. In a cluster analysis, they showed that that younger consumers are health conscious, while older consumers could be reached by promotional activities and extended shelf life.

\section{METHODOLOGY}

A structured questionnaire was applied in 9 department stores (3 large stores, 3 small stores and 3 bakeries), all of them located in the city of Juiz de Fora, Brazil. The department stores were chosen in different 
areas of the city, being 4 in downtown and 5 in the outskirts. After a pre-test, 248 people were interviewed in the real situation of purchase, i.e., while they were buying the product.

A binary logistic regression model was employed to analyze the consumer preference between whole and skimmed UHT milk, taking the purchase of skimmed milk as the event of interest. Whole milk consumption was taken as the reference category in the logit because it is the most consumed milk in Brazil. Purchase decision processes are composed of several variables that influence consumer choices (Cantallops \& Salvi, 2014). The following explanatory variables were taken into account: gender, age, educational level, type of housing, number of residents in the household, family income, frequency of milk consumption, volume consumed and last price paid. The variables educational level, number of residents in the household and family income are the ones that could reflect the impact of the new scientific findings about fat, as in Brazil, higher education indicates people that are more linking with science; the higher the number of residents, the lower connection to new scientific findings; and the lower family income also indicates low level of education and low level of connection to new scientific findings.

The best predictor variables were selected using a backward stepwise procedure based on minimizing the Akaike Information Criterion (AIC) and the final model was defined manually by Analysis of Deviance (ANODEV), by means of Chi-square tests (Collett, 2003). The analyses were conducted using R software version 3.4 .2 and results were reported as odds ratios (ORs) with $95 \%$ confidence intervals (Wald-type CIs).

\section{RESULTS AND DISCUSSION}

In the stepwise selection, education level, volume of consumption, frequency of consumption, last price paid and type of housing were removed from the model, and, in the subsequent ANODEV, the gender variable was also excluded. Thus, the final model contained age, family income and number of residents, with a residual deviance of 221.8 on 209 degrees of freedom (31 rows of data were excluded due to missing information for family income).

Table 1 presents the ORs with their 95\% CIs for the model's estimated coefficients. Family income and age coefficients are positive, so that their estimated ORs are greater than unity, and therefore the

Table 1. Odds ratio estimates and 95\% level confidence intervals for the coefficients obtained for the final adjusted model.

\begin{tabular}{cccc}
\hline Coefficient & OR estimate & Lower bound & Upper bound \\
\hline Intercept & 0.14 & 0.03 & 0.62 \\
$2-3 \mathrm{MW}^{*}$ & 3.53 & 0.99 & 12.57 \\
$3-6 \mathrm{MW}$ & 1.22 & 0.37 & 3.99 \\
$6-10 \mathrm{MW}$ & 3.61 & 1.01 & 12.88 \\
$10-15 \mathrm{MW}$ & 3.26 & 0.78 & 13.69 \\
$>15 \mathrm{MW}$ & 15.72 & 2.68 & 92.21 \\
age & 1.03 & 1.01 & 1.05 \\
no. residents & 0.71 & 0.55 & 0.92 \\
\hline * The first income class (up to two Minimum Wages $[\mathrm{MW}]$ ) was set as the reference category for the categorical variable "family income".
\end{tabular}


probability of purchasing skimmed milk instead of whole milk increases as these variables increase. However, as practically all the CIs for the ORs estimated for income classes varying from 2-3 MW to 10-15 MW include unity, consumers of these classes do not differ significantly, with respect to the preference for one of the two types of milk, from those included in the first income class, formed by those who earn up to two MW and which were left in the reference category for this variable. Thus, a significant difference for this variable was found only for the sixth income class, whose consumers would be approximately 16 times more likely to buy a skimmed rather than whole milk, when compared to a consumer belonging to the $1 \mathrm{st}$ income class, earning up to 2 minimum wages. Nevertheless, in spite of this quite strong punctual estimate of 15.7, obtained for the selected sample, we can stay confident that an individual randomly chosen from the studied consumers' population, pertaining to the 6th income class, is at least 2.7 more likely to buying skimmed UHT milk than whole UHT milk, than if he or she was from the 1 st income class.

Also from Table 1, we can see that for each one-year increase in age, the odds of purchasing skimmed instead of whole milk increases by $3 \%$. Meanwhile, this odds decreases as the number of household members increase, since its estimated OR was lower than unity. For each additional member living in the household, the odds of whole milk consumption, instead of skimmed UHT milk, is that increases by $41 \%$ $(\mathrm{OR}=1 / 0.71=1.41 ; 95 \% \mathrm{CI}: 8.70-81.82)$.

By making use of the model, we could also estimate the maximum probability of consumption of each type of milk for the extreme opposite profiles of consumers concerning the dichotomy skimmed-whole
UHT milk. In doing this, we would find that a consumer, with the characteristics of the sample under study, who belongs to highest income class (earning more than $15 \mathrm{MW}$ ), being the oldest possible person of the sample (that is, at 72 years of age) and living along with the fewest number of residents (i.e., residing alone), would have a probability of consumption of skimmed UHT milk as high as 92\% (95\% CI: 68\%-98\%). Oliveira and Hoffmann (2015) also found that higher incomes are associated with a higher probability to consume light/diet products or organic foods in Brazil. With the opposite profile, an individual from the first income class (earning up to two MW), being the youngest possible person of the sample (that is, at 18 years of age) and living along with the greatest number of residents considering the studied sample (five, in this case), would have a probability of consumption of skimmed UHT milk of only $4 \%(95 \% \mathrm{CI}: 1 \%-14 \%)$, that is, this person would be much more likely to consume whole than skimmed UHT milk.

\section{CONCLUSION}

Milk is an important part of the Brazilian diet. However, little is known about the factors affecting the consumer's decision to choose between whole and skimmed UHT milk. This paper was a preliminary study to investigate the consumers preferences for fat milk in Brazil.

Results indicated that the income, age and number of residents are the major determinants of consumer behaviour when choosing between whole and skimmed milk. Higher income, older people, and smaller number of residents increases the chance to consume skim milk. As de opposite, lower 
income, younger people and higher number of residents increases the probability of whole UHT milk consumption. It could suggest that the new scientific findings have not yet been assimilated by the population. It is also an indicative that dairy managers should orientate their market campaign and logistic distribution of products for these specific market groups.

\title{
ДЕТЕРМИНАНТЕ ПОНАШАҢА ПОТРОШАЧА ПРИЛИКОМ ИЗБОРА ИЗМЕБУ ПУНОМАСНОГ И ОБРАНОГ УХТ МЛЕКА
}

\author{
Kennya Beatriz Siqueira, Marielli Cristina de Pinho, \\ Cristiano Amâncio Vieira Borges, Marco Antonio Sundfeld da Gama
}

\begin{abstract}
Апстракт
У Бразилу се конзумира велика количина УХТ млека, али мало се зна о факторима који утичу на одлуку потрошача да одабере између пуномасног и обраног УХТ млека. Обзиром да потрошачи представљају један од главних покретача на тржишту, важно је идентификовати факторе који утичу на њихове обрасце понашања. Структурирани упитник је примењен на 248 људи из Јуиз де Фора, у Бразилу. Модел бинарне логистичке регресије коришћен је за анализу вероватноће куповине пуномасног или обраног УХТ млека. Резултати су показали да су приход, старост и број чланова породице у домаћинству главне одреднице понашања потрошача приликом избора између пуномасног и обраног млека. Већи приходи, старији људи и мањи број чланова домаћинства били су повезани са повећаном потрошњом обраног млека. Ови резултати би могли бити корисни за оријентацију кампања на локалном тржишту млека и за логистичку дистрибуцију производа према преференцијама потрошача.
\end{abstract}

Кључне речи: млечна маст, млечне прерађевине, потрошња, преференције

\section{References}

Astrup, A. (2014). A changing view on SFA and dairy: from enemy to friend. American Journal of Clinical Nutrition, 100 (6), 1407-1408.

Cantallops, A.S., \& Salvi, F. (2014). New consumer behavior: A review of research on EWOM and hotel. International Journal of Hospitality Management, 36, 41-51.

Collett, D. (2003). Modelling Binary
Data, 2nd edition. Chapman and Hall, London.

Grebitus, C., Yue, C., Bruhn, M., \& Jensen, H.H. (2007). Milk-marketing: impact of perceived quality on consumption patterns. In Canavari, M., Regazzi, D., \& Spadoni, R. (Eds.), Proceedings CD-ROM of the 105th Seminar of the European Association of Agricultural Economists, Bologna, 215-232.

Hatirli, S.A., Ozkan, B., \& Aktas, A.R. 
(2004). Factors affecting fluid milk purchasing sources in Turkey. Food Quality and Preference, 15 (6), 509-515.

IBGE - Instituto Brasileiro de Geografia e Estatística (2018, March 10). Pesquisa Industrial Anual 2018. Retrieved from: http://www.ibge.gov.br/

Kratz M., Baars, T., \& Guyenet, S. (2013). The relationship between high-fat dairy consumption and obesity, cardiovascular, and metabolic disease. European Journal of Nutrition, 52 (1), 1-24.

Maijala, K. (2000). Cow milk and human development and well-being. Livestock Production Science, 65 (1-2), 1-18.

Mozaffarian, D. (2014). Saturated fatty acids and type 2 diabetes: more evidence to re-invent dietary guidelines. Lancet Diabetes \& Endocrinology, 2 (10), 770-772.

Oliveira, F.C.R., \& Hoffmann, R. (2015) Consumption of organic foods and light or diet products in Brazil: conditioning factors and income elasticities (in Portuguese). Segurança Alimentar e Nutricional, Campinas, 22 (1), 541-557.

Saba, A., Moneta, E., Nardo, N., \& Sinesio, F. (1998). Attitudes, habit, sensory and liking expectation as determinants of the consumption of milk. Food Quality and Preference, 9 (1-2), 31-41.

Siqueira, K.B. (2018, March 13). Trends for the butter market in 2017 (in Portuguese). Retrieved from Milkpoint: https://www.milkpoint.com.br/artigos/espac o-aberto/tendencias-para-o-mercado-demanteiga-em-2017-104872n.aspx.

Yakoob, M.Y., Shi, P., Hu, F.B., Campos, H., Rexrode, K.M., Orav, E.J., Willett, W.C., \& Mozaffarian, D. (2014) Circulating biomarkers of dairy fat and risk of incident stroke among U.S. men and women in 2 large prospective cohorts. American Journal of Clinical Nutrition. 100 (6), 1437-1447.
WHO - World Health Organization (2015). Eliminating trans fats in Europe. A policy brief. Retrieved January 25, 2018 $\mathrm{f} r \mathrm{r} \quad \mathrm{m}$ http://www.euro.who.int/_data/assets/pdf_f ile/0010/288442/Eliminating-trans-fats-inEurope-A-policy-brief.pdf. 